\title{
Food phytochemicals against Helicobacter pylori
}

\author{
Alexandru $\mathrm{MANDICl}^{1}$, Alina-Alexandra COVRIG ${ }^{2}$, Irina $\mathrm{MACOVEI}^{3}$ \\ ${ }^{1}$ Department of Pharmacognosy, Faculty of Pharmacy, \\ "Grigore T. Popa" University of Medicine and Pharmacy, lasi, Romania \\ ${ }^{2}$ Department of Oncology, Regional Institute of Oncology, lasi, Romania \\ ${ }^{3}$ Department of Drug analysis, Faculty of Pharmacy, Grigore T. Popa University of Medicine and Pharmacy, lasi,
}

Romania

\begin{abstract}
H. pylori is a widespread pathogen, being the main culprit behind gastric and peptic ulcers with possible implications in the development of gastric cancers. In vitro studies have shown that ellagic acid and derivatives present in significant amounts in fruits and leaves have moderate bactericidal effects on $\mathrm{H}$. pylori, while resveratrol was noted to inhibit urease enzyme as high as $90 \%$ in different strains of H. pylori. Quercetin seems to inhibit pathogen's VacA enzyme and kaempferol may prevent translocation of CagA, both phytochemicals being found in significant amounts in berries. In one clinical study, allicin was found to act synergically with standard antibiotic regimens. Although in vitro results seem promising, in vivo studies did not underline significant clinical benefits of phytochemicals compared to standard therapy. Therefore, further studies are needed to accurately estimate any clinical benefit of dietary phytochemicals in $H$. pylori infection.
\end{abstract}

Keywords: Helicobacter infection, phytochemicals, plant origin

\section{INTRODUCTION}

Research conducted in the past decades suggests that Helicobacter pylori has been an important part of the human oral and stomach bacterial flora for at least 58.000 years (1). While being present in the flora of approximately $50 \%$ of the world's population, only $20 \%$ of those infected develop clinical symptoms (2).

H. pylori plays a significant role in the gastric and peptic ulcers etiology, and it is also a suspect in the later development of gastric lymphoma and cancer (2), the gastric cancer risk in infected people being 2 to 7 times higher compared with the uninfected people. Approximately $1-3 \%$ of the patients with active gastric or peptic ulcers progress to cancers and more than half of the gastric cancer patients also have an $\mathrm{H}$. pylori infection (3). World Health Organization (WHO) classified H. pylori as a group I carcinogen in 1994 (4), with a higer infection rate in the developing countries (70-80\%) compared to $13-50 \%$ in the developed ones (5).

H. pylori is a Gram-negative bacillus, spirilliform bacteria, that uses flagella to move rapidly and perform a 'tunneling' operation in the mucus covering the gastric epithelium. The complete mechanism by which it infects its host has been described elsewhere $(6,7,8)$. Briefly, using urease, an enzyme specific for 
this pathogen, it transforms urea present in the stomach to carbon dioxide and ammonia. As a result, the $\mathrm{pH}$ of the gastric environment increases allowing bacteria to use other mechanisms to continue the infectious process. Urease might be a short-term survival solution in the low $\mathrm{pH}$ stomach environment and the flagella for movement towards the neutral $\mathrm{pH}$ $(9,10,11)$. Also, H. pylori seems to posses chemotactic motility towards the mucus layer through urea- and bicarbonate-mediated mechanism (6). From there it can deploy highly immunogenic protein (CagA) and/or vacuolization-inducing protein (VacA) to epithelial cells, activating inflammatory and immune responses (7).

Eradication relies on the type and duration of the infectious process, antibiotic resistance and patients' compliance to therapy. Regimens are usually prescribed for 10-14 days, have two or three antibiotics (amoxicillin, clarithromycin and a proton pump inhibitor-PPI- or bismuth) and have $85-90 \%$ eradication rates (12). Despite that, there still is a notable increase of antimicrobial resistance to antibiotics, correlated with the standard prescriptions failure to eradicate the pathogen and with their adverse effects (nausea, diarrhea, headaches, skin rash) which have a significant impact on patients' compliance, treatment's success and costs, the treatment being inaccessible to the majority of the population $(13,14,15,16)$. As a result, efforts to find an efficient and low-cost alternative, other than antibiotics, are being made by the scientific community.

In the quest for novel compounds with potential benefits in preventing $H$. pylori infection, phytochemicals have received a considerable attention (17). While they do not eradicate H. pylori permanently, they can substantially reduce bacterial colonisation, inflammatory responses and mucosal atrophy and have shown synergistic effects with antibiotics, thus reducing the antibiotic dose and preventing undesirable side effects $(17,18)$.

\section{ELLAGIC ACID}

Ellagic acid (EA) and ellagitannins (ETs) occur naturally in foods, usually in walnuts, arctic bramble, strawberries, pomegranates, raspberries and red raspberries $(19,20)$. Currently, there is no consensous over dietary ETs and EA intake estimates as there is limited information on the precise content of the aforementioned phytochemicals in different plant species. Scalbert and Wiliamson (2000) estimate a 1g/ day total dietary intake of ETs and EA, although it varies considerably by different geographic regions (21). For example, in France it is estimated to be $0.2-0.3 \mathrm{mg} /$ day (22), while in Finland it is aproximately $12 \mathrm{mg} /$ day (23), in the German region of Bavaria it is estimated to range between 4.9-5.4 mg/day (24) and in Spain between 2590-3016 mg/day (25). However, recent estimates suggest that ETs intake may be much higher than previously estimated, especially if ET-rich foods are consumed daily (26).

Significant amounts of EA and ETs can be found in berries of the Rosaceae family (raspberry, strawberry, cloudberry), while in Elaeagnaceae family the levels are lower (27). On the other hand, grapefruits, peaches, red apples, pears, cherries, elderberries, blue plums, kiwi, navel oranges, peanuts, cashews and Brazil nuts have EA concentrations below the detection limit of HPLC systems (28). Kähkönen et al. (2001) found that ETs were the main phenolics in the genus Rubus (cloudberry and raspberry), while in Fragaria (strawberry) genus they were placed second after anthocyanins. EA levels showed variation from $47 \mathrm{mg} / \mathrm{g}$ in raspberries to $90 \mathrm{mg} / \mathrm{g}$ in black raspberries $(29,30)$. Available data on EA content of fresh raspberries varies by study. Koponen et al. (2007) have found $263.7 \mathrm{mg}$ EA/100g product, Daniel et al. (1991) detected 103.0 $\pm 3.3 \mathrm{mg} \mathrm{EA} / 100 \mathrm{~g}$ product and Kähkönen et al. (2001) detected as much as 1794 mg $E A / 100$ g product $(28,29,31)$. The same quantitative variability applies for strawberries, EA ranging from 31 $\mathrm{mg} / 100 \mathrm{~g}$ product to as high as $184 \mathrm{mg} E \mathrm{E} / 100 \mathrm{~g}$ product $(29,32)$. More estimated EA content in different, commonly encountered fruits and seeds and determined by various authors, are shown in Table 1.

Plant products with a high content of phenolic derivatives, especially EA and ETs have shown promising in vitro bacteriostatic effects. A study conducted by Chung (1998) revealed that EA has dosedependent bactericidal effects on clinical isolates of $H$. pylori, the most potent bactericidal dose being IC50 = $1 \mathrm{mM}$ (33). Martini et al. (2009) showed that Rubus ulmifolius leaves extract had a moderate in vitro bactericidal effect on two $H$. pylori strains (MBC = $1200 \mu \mathrm{g} / \mathrm{ml}$ and $1500 \mu \mathrm{g} / \mathrm{ml}$ after $24 \mathrm{~h}$ exposure and $\mathrm{MBC}=134 \mu \mathrm{g} / \mathrm{ml}$ and $270 \mu \mathrm{g} / \mathrm{ml}$ after $48 \mathrm{~h}$ ) compared to EA control (34). 
TABLE 1. Ellagic acid (EA) content in commonly consumed fruits and seeds

\begin{tabular}{|c|c|c|}
\hline Fruits & EA content (mg/100g fresh product) & Reference \\
\hline Arctic bramble & 390 & Määttä-Riihinen et al. (2004) \\
\hline Blackberries & $150.0 \pm 12.0$ & Daniel et al. (1989) \\
\hline Black raspberries & 90 & \multirow{2}{*}{ Wada and Ou (2002) } \\
\hline Boysenberries & 70 & \\
\hline Cloudberry & $\begin{array}{c}315.1 \\
1090-1432 \\
360\end{array}$ & $\begin{array}{c}\text { Koponen et al. (2007) } \\
\text { Kähkönen et al. (2001) } \\
\text { Määttä-Riihinen et al. (2004 }\end{array}$ \\
\hline Cranberry & $12.0 \pm 0.4$ & Daniel et al. (1989) \\
\hline Raspberry & $\begin{array}{c}263.7 \\
150.0 \pm 10.0 \\
1692-1794 \\
270 \text { (wild) }\end{array}$ & $\begin{array}{l}\text { Koponen et al. (2007) } \\
\text { Daniel et al. (1989) } \\
\text { Kähkönen et al. (2001) } \\
\text { Määttä-Riihinen et al. (2004) }\end{array}$ \\
\hline Raspberry (yellow) & 1900 & Määttä-Riihinen et al. (2004) \\
\hline Strawberry & $\begin{array}{c}81-184 \\
65-85 \\
63.0 \pm 9.0 \\
31 \\
\end{array}$ & $\begin{array}{c}\text { Kähkönen et al. (2001) } \\
\text { Määttä-Riihinen et al. (2004) } \\
\text { Daniel et al. (1989) } \\
\text { Mattila and Kumpulainen (2002) }\end{array}$ \\
\hline Walnuts & $59 \pm 0.1$ & \multirow{2}{*}{ Daniel et al. (1989) } \\
\hline Pecans & $33 \pm 0.3$ & \\
\hline Seeds & EA content ( $\mathrm{mg} / \mathrm{g}$ dried product) & Reference \\
\hline Marion blackberry & 32 & \multirow{5}{*}{ Bushman et al. (2004) } \\
\hline Boysenberry & 30 & \\
\hline Evergreen blackberry & 21 & \\
\hline Red raspberry & 8.7 & \\
\hline Black raspberry & 6.7 & \\
\hline Longan & 1.6 & \multirow{2}{*}{ Soong and Barlow (2006) } \\
\hline Mango & 1.2 & \\
\hline
\end{tabular}

\section{RESVERATROL}

Although resveratrol concentrations in common foods are very low, in wine the content was found to be 0.361-1.972 mg/l (red wine), $0.29 \mathrm{mg} / \mathrm{l}$ (rosé wine) and $0-1.089 \mathrm{mg} / \mathrm{l}$ (white wine) $(35,36,37)$. Other concentrations of resveratrol in foods are shown in Table 2.

In the recent years, the interest for phytoalexins such as resveratrol has grown as they might have potential antimicrobial activity against $\mathrm{H}$. pylori by inhibiting IL-8 secretion from $H$. pylori-infected cells at concentrations of 75-100 $\mu \mathrm{M}$ along with a reduction in reactive oxygen species reduction at concentrations between 1-100 $\mu \mathrm{M}(34,38,39,40)$.

Zhang et al. (2015) noted similar results in a mouse model of $H$. pylori infection. Orally administration of resveratrol $(100 \mathrm{mg} / \mathrm{kg} /$ day) for six weeks determined a reduction in $\mathrm{H}$. pylori- induced mRNA transcription and protein expression levels of inducible nitric oxide synthase (iNOS) and interleukin 8 (IL-8). It was also observed an increased activity of the potent antioxidant enzyme heme oxygenase-1 (HO-1) and for
TABLE 2. Resveratrol content in foods

\begin{tabular}{|c|c|c|}
\hline Food/Drink & Concentration & References \\
\hline Tomato skin & $\sim 19000 \mu \mathrm{g} / \mathrm{kg}$ & $\begin{array}{c}\text { Ragab et al. } \\
2006\end{array}$ \\
\hline Dark chocolate & $350 \mu \mathrm{g} / \mathrm{kg}$ & \multirow{2}{*}{ Hurst et al. 2008} \\
\hline Milk chocolate & $100 \mu \mathrm{g} / \mathrm{kg}$ & \\
\hline Itadori tea & $68 \mu \mathrm{g} / 100 \mathrm{ml}$ & $\begin{array}{c}\text { Burns et al. } \\
2002\end{array}$ \\
\hline Red grapes & $92-1604 \mu \mathrm{g} / \mathrm{kg}$ & \multirow{2}{*}{$\begin{array}{c}\text { Okuda and } \\
\text { Yokotsuka } 1996\end{array}$} \\
\hline White grapes & $59-1759 \mu \mathrm{g} / \mathrm{kg}$ & \\
\hline Apples & $400 \mu \mathrm{g} / \mathrm{kg}$ & $\begin{array}{c}\text { Farneti et al. } \\
2015 \\
\end{array}$ \\
\hline Beer & $1.34-77 \mu \mathrm{g} / \mathrm{L}$ & $\begin{array}{c}\text { Chiva-Blanch et } \\
\text { al. } 2011\end{array}$ \\
\hline Peanuts (no coats) & $30-140 \mu \mathrm{g} / \mathrm{kg}$ & $\begin{array}{c}\text { Sanders et al. } \\
2000 \\
\end{array}$ \\
\hline
\end{tabular}

the nuclear factor-erythroid 2 related factor 2 (Nrf2) which upregulates the antioxidant response. Cumulated with the effect of supression H. pyloriinduced phosphorylation of nuclear factor of kappa light polypeptide gene enhancer in B-cells inhibitor $(\mathrm{I} B \mathrm{~B} \alpha)$, resveratrol showed significant activities against oxidative stress and inflammation (41). Paulo et al. (2011) noted that resveratrol, at a concentration of 
$400 \mu \mathrm{g} / \mathrm{ml}$, seems to decrease urease activity by $90 \%$ in some strains of H. pylori (42).

\section{ALLICIN AND ALLIXIN}

Allicin is an oxygenated sulfur-containing volatile compound present in Allium species, mainly in Allium sativum (garlic). It accounts for aproximately $70 \%$ $(\mathrm{w} / \mathrm{w})$ of the total garlic thiosulfinates. In one fresh crushed garlic clove there is aproximately 4-5 mg of allicin. Allicin is an unstable compound and it is rapidly degraded under the influence of temperature and $\mathrm{pH}$ $(43,44)$. Acidic solutions (e.g. vinegar) seem to increase allicin's lifespan to $10-17$ days, by lowering the $\mathrm{pH}(45,46)$.

Allixin is also a non-sulfur compound and it was the first phytoalexin isolated from Allium sativum. It is a secondary metabolite released by plants during stressful conditions and seems to possess some antimicrobial activities. However, bioavailability of allixin alone was noted to be very low $(47,48)$.

Both allicin and allixin are very reactive and unstable, thus, it is questionable if there are any therapeutical benefits when administered orally as they have low bioavailability, are quickly decomposed to other organosulfur, antimicrobial-inactive compounds and quickly react with thiol groups from aminoacids (49, 50).

Despite the drawbacks, in vitro studies using simulated gastric environment have shown that garlic inhibits colonization and bacterial growth, including $H$. pylori (51). Also, Cellini et al. (1996) found that a cold aqueous extract from garlic cloves has anti-H. pylori properties at concentrations ranging from 2 to $5 \mathrm{mg} /$ $\mathrm{ml}$ in an agar plate assay (52). Kockar et al. (2001) evaluated the potential benefits of allicin, ascorbic acid and beta-carotene in treating $H$. pylori infection in a randomized, controled trial (210 patients) compared to the standard regimen and whether there was synergy with the standard treatment. Infection eradication has been achieved in approximately 27 patients $(90 \%)$ from the group treated with standard regimen and allicin $4200 \mu \mathrm{g} /$ day. Still, only seven patients $(23.3 \%)$ from the group treated with allicin only (1200 $\mu \mathrm{g} /$ day) had the infection eradicated, while ascorbic acid and beta carotene had no effect. The study noted the effectiveness of allicin as an add-on therapy to the standard regimen (53).
In a prospective, crossover study conducted on $27 \mathrm{H}$. pylori-infected adults, Graham et al. (1999) compared the administration of fresh garlic and capsaicin-cantaining peppers (jalapenos) with a bismuth subsalicylate positive control group and a negative control group using 13C-urea breath test. They found that neither garlic nor jalapenos had any in vivo effect on $\mathrm{H}$. pylori compared to bismuth subsalicylate (54).

The aforementioned studies show contrasting results. In vitro studies have shown some inhibitory effect of garlic and/or allicin on $\mathrm{H}$. pylori $(51,52)$, while in vivo studies have shown no benefit from associating garlic with standard treatment or garlic alone $(53,54)$.

\section{EPIGALLOCATECHIN GALLATE AND DERIVATIVES}

Epigallocatechin (EGCG) and its derivatives are the most abundant in green tea (Camelia sinensis), constitute aproximately $40 \%$ of the total polyphenol content and posessess various health benefits through their potent antiinflammatory and antioxidant activities (55). In H. pylori infections, EGCG seems to inhibit glycosylation of $\mathrm{H}$. pylori-induced toll-like receptor 4 (TLR-4) signaling pathway induced by the pathogen alongside with the inhibition of urease enzyme and diminishing DNA damage and gastric mucosa cytotoxicity of epithelial cells induced by $\mathrm{H}$. pylori (56). Also, green tea inhibited the in vitro growth of $H$. pylori at a MIC90 of $0.25-0.5 \%(w / w)$, while pure EGCG and epicatechin inhibited its growth at a MIC90 of $50-100 \mu \mathrm{g} / \mathrm{ml}$ and $800-1600 \mu \mathrm{g} / \mathrm{ml}$, respectively (57). Nonetheless, caution is required when extrapolating in vitro results to in vivo recommendations.

\section{CHLOROGENIC ACID}

Coffee and green tea are the most abundant sources of chlorogenic acid (CGA). In literature data, CGA concentrations in green coffee seeds vary from 4 to $8.4 \mathrm{~g} / 100 \mathrm{~g}$ dried product. In contrast, in roasted beans, they range from 0.3 to $3.5 \mathrm{~g} / 100 \mathrm{~g}$, including lactones formed during roasting (58). Daily intake doses of CGA may vary between 100 and 1000 mg. There are no daily recommended doses as there are no studies that directly link doses to various pharmacological effects (22). 
CGA has been reported to inhibit urease in $\mathrm{H}$-pylori (59). $H$. pylori growth is inhibited by CGA isolated from Anthemis altissima extracts at a MIC $=312.5 \mu \mathrm{g} / \mathrm{ml}$ and $1250 \mu \mathrm{g} / \mathrm{ml}$, respectively (60). Studies conducted by Paun et al (2014) on Geranium robertianum, Hyssopus officinale and Helleborus purpurascens extracts having CGA in composition $(1.5 \mathrm{mg} / \mathrm{L}$ herbal extract) reported urease inhibitory effects. CGA isolated from apricot fruits extract (Prunus armeniaca $L$.) has antimicrobial activity against $H$. pylori at a MIC $20.313 \mu \mathrm{g} / \mathrm{ml}$, while the mechanism of action remains to be uncovered $(61,62)$.

\section{QUERCETIN AND KAEMPFEROL}

Quercetin is a flavonoid present in various fruits and vegetables, thus being a common element in the human diet. It is estimated that the daily intake in humans is approximately 5-40 mg quercetin (63). Berries have the highest content of quercetin per $\mathrm{kg}$ of fresh product, bog whortleberry, lingoberry and cranberry leading with concentrations up to $158 \mathrm{mg} /$ $\mathrm{kg}$, 74- $146 \mathrm{mg} / \mathrm{kg}$ and 83-121 mg/kg, respectively. Other berries are located at the lower end of the spectrum, such as rowanberry $(63 \mathrm{mg} / \mathrm{kg})$, sea buckthorn berry (62 mg/kg) and crowberry (53 and 56 $\mathrm{mg} / \mathrm{kg}$ ) (19). Quercetin is also present in spring onion leaves ( $841 \pm 8 \mathrm{mg} / \mathrm{kg}$ dry product) and white onion bulls ( $50 \pm 9 \mathrm{mg} / \mathrm{kg}$ dry product). Apples and especially apple peels have reasonable amounts of quercetin ( $250 \pm 4 \mathrm{mg} / \mathrm{kg}$ dry product). At the same time, Hyperici herba (Hypericum perforatum) contains $13.3 \pm 1.2 \mathrm{mg} / \mathrm{kg}$ dry product, whereas Sambuci flos (Sambucus nigra) have the lowest content in quercetin, about $7.9 \pm 0.7 \mathrm{mg} / \mathrm{kg}$ dry product (64).

Along with its potent free radical scavenging, cardioprotective, hypotensive, anti-atherosclerotic, antidiabetic and antitumor activities, quercetin has also been reported to possess anti- $H$. pylori activity by inhibiting the vacuolating enzyme VacA at an IC50= 19 $\mu \mathrm{M}(63,65,66)$. However, in a mouse model of $\mathrm{H}$. pylori infection, quercetin did not eradicate the infection, but it lowered the bacterial numbers in the Conflict of interest: none declared Financial support: none declared quercetin treated group compared with the infected control (67). Regarding the daily flavonoid intake in humans, Hollman et al. (1996) reported aproximately $23 \mathrm{mg} /$ day, of which quercetin makes up for aproximately $16 \mathrm{mg} /$ day (68).

Kaempferol showed a significant inhibitory effect on two $\mathrm{H}$. pylori strains, as a $15 \mathrm{~mm}$ diameter of inhibition was noted for a concentration of $1 \mathrm{mg} / \mathrm{ml}$. Moreover, In association with $50 \mu \mathrm{g} / \mathrm{ml}$ (-)-epicatechin, $150 \mu \mathrm{g} / \mathrm{ml}$ kaempferol seemed to produce a synergistic effect against $H$. pylori, inhibiting the growth of $H$. pylori strains in liquid culture medium with $\mathrm{CFU} / \mathrm{ml}=1.4 \times 103$ (69). In vitro studies carried on gastric adenocarcinoma cell line showed that kaempferol reduced the expression of proinflammatory cytokines TNF- $\alpha, \mathrm{IL}-1 \beta$ and production of IL-8, thus exhibiting antiinflammatory effects in $H$. pylori-induced inflammation. Additionally, it suppressed translocation of cytotoxin-associated gene A (CagA) and vacuolating cytotoxin A (VacA), both virulence factors generated by $H$. pylori (70). Similarly to quercetin, there are no dietary guidelines regarding kaempferol intake. The highest kaempferol content is in onion leaves ( $832.0 \mathrm{mg} / \mathrm{kg}$ product) while in berries it had been detected only in gooseberries (16 and 19 $\mathrm{mg} / \mathrm{kg}$ ) and strawberries (5 and $8 \mathrm{mg} / \mathrm{kg})(19,71)$.

\section{CONCLUSIONS}

Although in vitro studies suggest that some phytochemicals present in the diet might possess a potential antimicrobial activity in $H$. pylori infection, findings from in vitro studies cannot be extrapolated to in vivo studies, as results are conflicting. Further research is needed to determine whether phytochemicals may represent a viable alternative as an add-on therapy to standard regimens used to treat infection with $H$. pylori.

\section{Author contributions}

Alexandru Mandici - conceptualization, original draft preparation, editing; Alina-Alexandra Covrig - data collection; Irina Macovei - review, editing. 


\section{REFERENCES}

1. Linz B, Balloux F, Moodley $Y$, et al. An African origin for the intimate association between humans and Helicobacter pylori. Nature. 2007;445:915-918.

2. Percival SL, Suleman L. Biofilms and Helicobacter pylori: Dissemination and persistence within the environment and host. World J Gastrointest Pathophysiol. 2014;5:122.

3. Covacci A, Telfor J, Del Giudice G et al. Helicobacter pylori virulence and genetic geography. Science. 1999;284:1328-1333.

4. World Health Organization. IARC monographs on the evaluation of carcinogenic risks to humans, vol. 61. Geneva: World Health Organization. 1994;177-240.

5. Palateiro B, Bastos A, Ferro A et al. Prevalence of Helicobacter pylori infection worldwide: a systematic review of studies with national coverage. Dig Dis Sci. 2014;118:426-430.

6. Yoshiyama $\mathrm{H}$, Nakazawa $\mathrm{T}$, Unique mechanism of Helicobacter pylori for colonizing the gastric mucus. Microbes Infect. 2000;2:5560.

7. Kusters JG, van Vliet AHM, Kuipers EJ, Pathogenesis of Helicobacter pylori infection. Clin Microbiol Rev. 2006;19:449-490.

8. Wang Y-C, Medicinal plant activity on Helicobacter pylori related diseases. World J Gastroenterol. 2014;20: 10368-10382.

9. Nakamura $\mathrm{H}$, Yoshiyama $\mathrm{H}$, Takeuchi $\mathrm{H}$ et al. Urease plays an important role in the chemotactic motility of Helicobacter pylori in a viscous environment. Infect Immun. 1998;66:4832-4837.

10. Schreiber S, Konradt M, Groll C et al. The spatial orientation of Helicobacter pylori in the gastric mucus. Proc Natl Acad Sci. 2004;101:5024-5029.

11. Schreiber S, Bucker R, Groll C, et al. Rapid loss of Helicobacter pylori in the gastric lumen in vivo. Infect Immun. 2005;73:1584-1589.

12. Salehi B, Sharopov F, Martorell M et al. Phytochemicals in Helicobacter pylori: What Are We Doing Now? Int I Sci. 2018;19:2361.

13. Gisbert J, Gonzalez L, Calvet $\mathrm{X}$ et al. Proton pump inhibitor, clarithromycin and either amoxycillin or nitroimidazole: $\mathrm{A}$ meta-analysis of eradication of Helicobacter pylori. Aliment Pharmacol. 2000;14:1319-1328.

14. Lansdorp-Vogelaar I, Sharp L, Cost effectiveness of screening and treating Helicobacter pylori for gastric cancer prevention. Best Pract Res Clin Gastroenterol. 2013;27:933-947.

15. Molina-Infante J, Gisbert JP, Optimizing claritrhromycin-containing therapy for Helicobacter pylori in the era of antibiotic resistance. World J Gastroenterol. 2014;20:10338-10347.

16. Hsu P-L, Wu D-C, Chen W-C et al. Randomised controled trial comparing 7-day triple, 10-day sequential and 7-day concomitant therapies for Helicobacter pylori infection. Antimicrob Agents Chemother. 2014;58:5936-5942.

17. Fahey JW, Stephenson KK, Wallace AJ, Dietary amelioration of Helicobacter infection, Nutrition Res. 2015;461-473.

18. Wang X, Hirmo S, Willen R et al. Inhibition of Helicobacter pylori infection by bovine milk glycoconjugates in a BAlb/cA mouse model. J Med Microbiol. 2001;50:430-435.

19. Häkkinen SH, Kärenlampi SO, Heinonen IM et al. Content pf the Flavonols Quercetin, Myricetin, and Kaempferol in 25 Edible Berries. J Agric Food Chem. 1999;47: 2274-2279.

20. Khanbabae K, van Ree T. Tannins: Classification and definition. Nat Product Rep. 2001;18:641-649.

21. Scalbert A, Williamson G, Dietary intake and bioavailability of polyphenols, J Nutr. 2000;130:2073-2085.

22. Clifford MN, Scalbert A, Ellagitannins- Nature, occurrence and dietary burden. J Sci Food Agric. 2000;80: 1118-1125.

23. Ovaskaien ML, Toronen R, Koponen JM et al. Dietary intake and major food sources of polyphenols in Finnish adults, $J$ Nutr. 2008;138: 562-566.

24. Radtke J, Linseisen J, Wolfram G, Phenolic acid intake of adults in a Bavarian subgroup of the national food consumption survey, Zeitschrift für Ernährungswissenschaft. 1988;37:190-197.
25. Saura-Calixto F, Serrano J, Goni I, Intake and bioaccesibility of total polyphenols in whole diet. Food Chem. 2007;101:492-501.

26. Tomas-Barberan FA, Espin JC, Garcia-Conesa M, Bioavailability and metabolism of ellagic acid and ellagitannins, Quideau S. editor in Chemistry and biology of ellagitannins, World Scientific. London, 2009;273-297.

27. Landete JM, Ellagitannins, ellagic acid and their derived metabolites: a review about source, metabolism, functions and health. Food Res Int. 2011;44:1150-1160.

28. Daniel EM, Ratnayake $\mathrm{S}$, Kinstle $\mathrm{T}$ et al. The effects of $\mathrm{pH}$ and rat intestinal contents on the liberation of ellagic acid from purified and crude ellagitanins. J Nat Prod. 1991;54:946-952.

29. Kähkönen MP, Hopia AL, Heinonen M, Berry phenolics and their antioxidant activity. J Agric Food Chem. 2001;49: 4076-4082.

30. Wada L, Ou B, Antioxidant activity and phenolic content of Oregon caneberries, J Agric Food Chem. 2002;50:3495-3500.

31. Koponen JM, Happonen AM, Mattila PH et al. Contents of anthocyanins and ellagitannins in selected foods consumed in Finland. J Agric Food Chem. 2007;55:1612-1619.

32. Mattila P, Kumpulainen J, Determination of Free and Total Phenolic Acids in Plant-Derived Foods by HPLC with Diode-Array Detection, $J$ Agric Food Chem. 2002;50:3660-3667.

33. Chung JG, Inhibitory actions of ellagic acid on growth and arylamine $\mathrm{N}$-acetyltransferase activity in strains of Helicobacter pylori from peptic ulcer patients. Microbios. 1998;93:115-127.

34. Martini S, D'Addario C, Colacevich A et al. Antimicrobial activit against Helicobacter pylori strains and antioxidant proprieties of blackberry leaves (Rubus ulmifolius) and isolated compounds, Int/ J Antimicrob Agents. 2009;34: 50-59.

35. Jeandet $P$, Bessis R, Maume BF, Sbanghi M, Analysis of resveratrol in burgundy wine. J Wine Res. 1993;4:79-85.

36. Cvejic JM, Djekic SV, Petrovic AV et al. Determination of trans- - and cis-resveratrol in Serbian commercial wines. J Chromatogr Sci. 2010;48:229-234.

37. Romero-Perez Al Lamuela-Raventos RM, Buxaderas $S$ et al. Resveratrol and piceid as varietal markers of whine ines. J Agric Food Chem. 1996;44:1975-1978.

38. Mahadi GB, Penland SL, Resveratrol inhibits the growth of Helicobacter pylori in vitro, Am J Gastroenterol. 2000;95:1849.

39. Daroch $\mathrm{F}$, Hoeneisen $\mathrm{M}$, Gonzalez $\mathrm{CL}$ et al. In vitro antibacterial activity of Chilean red wines against Helicobacter pylori, Microbios. 2001;104:79-85.

40. Haider Zaidi SF, Ahmed K, Yamamoto T et al. Effect of Resveratrol on Helicobacter pylori-Induced Inerleukin-8 Secretion, Reactive Oxygen Species Generation and Morphological Changes in Human Gastric Epithelial Cells, Biol Pharma Bull. 2009;32:1931-1935.

41. Zhang X, Jiang A, Qi B et al. Resveratrol Protects against Helicobacter pylori-Associated Gastritits by Combating Oxidative Stress, Int J Mol Sci. 2015;16:27757-27769.

42. Paulo L, Oleastro M, Gallardo E et al. Anti-Helicobacter pylori and urease inhibitory activities of resveratrol and red wine. Food Res Int. 2011;44:964-969.

43. Rybak ME, Calvey EM, Harnly JM, Quantitative determination of allicin in garlic: Supercritical fluid extraction and standard addition of allicin, J Agric Food Chem. 2004;52:682-687.

44. Horev-Azaria L, Eliav S, Izigov N, Pri-Chen S et al. Allicin upregulates cellular glutathione level in vascular endothelial cells, Eur J Nutr. 2009;48:67-74.

45. Fujisawa H, Suma K, Origuchi K et al. Thermostability of allicin determined by chemical and biological assays, Biosci Biotech Biochem. 2008;72:2877-2883.

46. Wang $\mathrm{H}$, Li X, Liu X et al. Influence of $\mathrm{pH}$, concentration and light on stability of allicin in garlic (Allium sativum L.) aqueous extract as measured by HPLC, J Sci Food Agric. 2015;95:1838-1844.

47. Kodera Y, Matsuura H, Yoshida S et al. Allixin, a Stress Compound from Garlic, Chem Pharm Bull. 1989;37:1656-1658. 
48. Kodera Y, Ichikawa M, Yoshida J et al. Pharmacokinetic Study of Allixin, a Phytoalexin Produced by Garlic, Chem Pharm Bull. 2002;50:354-363.

49. Gao C., Jiang X., Wang H.. et al. Drug metabolism and pharmacokinetics of organosulfur compounds from garlic, J Drug Metabol Toxicol. 2013;4:159.

50. Leontiev R, Hohaus $\mathrm{N}$, Jacob $\mathrm{C}$ et al. A comparison of the antibacterial and antifungal activities of thiosulfinate analogues of allicin, Sci Rep. 2018;8: 6763.

51. O'Gara EA, Maslin DJ, Nevill AM et al. The effect of simulated gastric environments on the Helicobacter activity of garlic oil, Am J Gastroenterol. 2000;95:563-564.

52. Cellini L, Di Campli E, Masulli M et al. Inhibition of Helicobacter pylori by garlic extract (Allium sativum), FEMS Immunol Med Microbiol. 1996;13: 273-277.

53. Kockar C, Oztürk M, Bavbek N, Helicobacter pylori eradication with beta carotene, ascorbic acid and allicin, Acta Medica (Hradec Kralove). 2001;44:97-100

54. Graham DY, Anderson SY, Lang T. Garlic or jalapeno peppers for treatment of Helicobacter pylori infection, Am J Gastroenterol. 1999;94:1200-1202.

55. Yang F, Oz HS, Barve S et al. The green tea polyphenol (-)-epigallocatechin-3-gallate blocks nuclear factor-kappa B activation by inhibiting I kappa B kinase activity in the intestinal epithelial cell line IEC-6. Mol Pharmacol. 2001;60:528-533.

56. Lee KM, Yeo M, Choue JS et al. Protective mechanism of epigallocatechin-3-3gallate against Helicobacter pylori-induced gastric epithelial cytotoxicity via the blockage of TLR-4 signaling. Helicobacter. 2004;9:632-642.

57. Yee YK, Koo MW, Anti-Helicobacter pylori activity of Chinese tea: in vitro study. Aliment Pharmacol Ther. 2000;14:635-638.

58. Farah A, Duarte G, Chapter 87 - Bioavailability and Metabolsim of Chlorogenic Acids from Coffee, editor: Victor R. Preedy in Coffee in Health and Disease Prevention; Academic Press. 2015;719-801.

59. Lin YT, Kwon YI, Labbe RG et al. Inhibition of Helicobacter pylori and associated urease by oregano and cranberry phytochemical synergies. Appl Environ Microbiol. 2005;71:8558-8564.
60. Konstantinopoulou M, Karioti A, Skaltsas S et al. Sesquiterpene lactones from Anthemis altissima and their anti-Helicobacter pylori activity, J Nat Prod. 2003;66: 699-702.

61. Paun G, Litescu SC, Neagu E et al. Evaluation of Geranium spp. Helleborus spp. and Hyssopus spp. polyphenolic extracts inhibitory activity against urease and $\alpha$-chymotrypsin. J E nzyme Inhibit Med Chem. 2014;29: 28-34.

62. Mujtaba A, Masud T, Ahmad A et al. Antibacterial Activity by Chlorogenic Acid Isolated through Resin from Apricot (Prunus Armeniaca L.), Pak J Agric Res. 2017;30: 144-148.

63. Russo M, Spagnuolo C, Tedesco I et al. The flavonoid quercetin in disease prevention and therapy: facts and fancies. Biochem Pharmacol. 2012;83:6-15.

64. Wach A, Pyrzynska K, Biesaga M, Quercetin content in some food and herbal samples, Food Chem. 2007;100: 699-704.

65. Tombola F, Campello S, De Luca L et al. Plant polyphenols inhibit VacA, a toxin secreted by the gastric pathogen Helicobacter pylori, FEBS Letters. 2003;543.

66. Butkovic V, Klasinc L, Bors W, Kinetic study of flavonoid reactions with stable radicals. J Agric Food Chem. 2004;52:2816-2820.

67. Brown J, Wang J, Kasman L et al. Activities of muscadine grape skin and quercetin against Helicobacter pylori infection in mice. J App Microbiol. 2011;110:139-146.

68. Hollman PCH, Hertog MGL, Katan MB Analysis and health effects of flavonoids, Food Chem. 1996;57: 43-46.

69. Escandon RA, del Campo M, Lopez-Solis R et al. Antibacterial effect of kaempferol and (-)-epicatechin on Helicobacter pylori. Eur Food Res Tech. 2016;242:1459-1502.

70. Yeon MJ, Lee MH, Kim DH et al. Anti-inflammatory effects of Kaempferol on Helicobacter pylori-induced inflammation. Biosci Biotech Biochem. 2019;83:166-173.

71. Miean KH, Mohamed S, Flavonoid (Myricetin, Quercetin, Kaempferol, Luteolin, and Apigenin) Content of Edible Tropical Plants, J Agric Food Chem. 2001;49:3106-3112. 